\title{
Educational Linguistics
}

\section{MICHAEI STUBBS}

Michael Stubbs' book describes different dialects and styles of spoken, written and literary English, showing how such information is of practical pedagogic value to teachers. The book discusses in detail what should be taught in English lessons in schools, as well as considering broader educational questions such as the place of Standard English in the curriculum. 296 pages, $25.00 \quad(0631138986)$

\section{Literacy}

Teaching and Learning Language Skills

\section{Edited by ASHIBR CASHDAN}

Literacy is a working guide for teachers on developments in both the theory and practice of literacy teaching; covering writing, assessment, spelling, language and cognitive development. It includes a chapter on the introduction of computers in literacy programmes, as well as contributions from distinguished teachers at all levels.

208 pages, hardback $\$ 1.00(0631135545)$

paperback $\$ 6.50$ (0631 14279 7)

\section{Children's Writing and Reading}

\section{Analyzing Classroom Language \\ RATHARIUE PERERA}

"This well-organized book will be a valuable addition to the range of books on applied linguistics for teachers ... It will no doubt become one of the many reference books for teacher trainers and undergraduates.'

Times Higher Education Supplement

The Language Llorary

368 pages, hardback 57.50 (0 631136533$)$

paperback $\$ 8.95$ (0631 13654 1)

\section{Children's Conversation}

\section{MCHAEL MCTEAR}

"This book provides a valuable introduction to this relatively new area and clearly illustrates the insights and practical implications that emerge from the detailed examination of conversational activity.'

Times Higher Education Supplement

304 pages, hardback $27.50(0631$ 13984 2)

paperback 88.95 (0 631 142495)

\section{Children's Reading Problems}

Psychology and Education

\section{PETER BRYANT and LYNITTE BRADLEY}

'Its cheerful and unassuming style masks an uncompromising sharpness in its analysis of relevant research and the innovatory nature of the authors' own work.' Education

176 pages, hardback $619.50(0631136827)$

paperback 55.95 (0 631 136835)

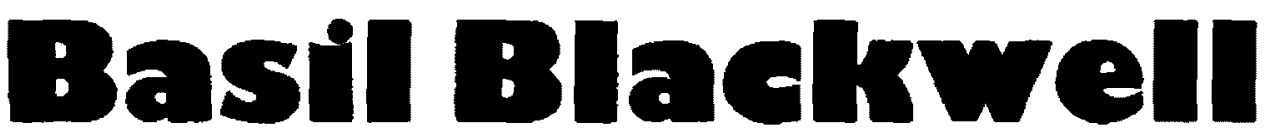

108 Cowley Road, Oxford OX4 1JF

Suite 1503, 432 Park Avenue South, New York NY 10016 


\title{
A. E. Mills, St. John
}

\section{The Acquisition of Gender}

\author{
A Study of English and German
}

1986. 14 figures, 26 tables. Approx. 180 pages. (Springer

Series in Language and Communication, Volume 20)

Hard cover DM 98,-- ISBN 3-540-16740-4

This book presents a cross-linguistic comparison of the acquisition of gender by German- and English-language speaking children. It reveals the complex nature of the acquisition process in which factors such as linguistic structure, linguistic functions and adult usage emerge as important. A detailed description of the gender system of the two languages together with data on children's acquisition in this area are presented.

The results of the studies are of general relevance for language acquisition theory: they show among other things that a description of linguistic system alone is not sufficient to predict the process of acquisition, that a measure of the rule 'clarity' is needed, and also that claims about the semantic base of language learning cannot be upheld.

\section{The Development of Word Meaning}

Progress in Cognitive Development Research

Editors: S. A. Kuczaj, II. Dallas; M. D. Barrett, London

1986. 21 figures. XVIII, 351 pages. (Springer Series in Cognitive Development). Hard cover DM 168,ISBN 3-540-96152-6

\section{J.P. Forgas, Giessen}

\section{Language and Social Situations}

1985. 14 figures. XVIII, 281 pages. (Springer Series in Social Psychology). Hard cover DM 108,-- ISBN 3-540-96090-2

Prices are subject to change without notice.

\section{Springer-Verlag} Berlin Heidelberg New York London Paris Tokyo

Heidelberger Platz 3, D-1000 Bertin 33. 175 Fifth Ave. New York. NY 10010, USA 28 , Lurke Streel, Bedford MK40 3HU, England - 26, nue des Carmes, F-75005 Paris 37-3, Hongo 3-chome, Bunkyo-ku, Tokyo 113, Japan

\section{Springer}

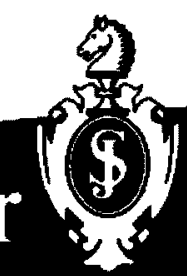




\section{Journal of Child Language}

Volume 13

I 986

Number 1: $1-189$

Number 2: $191-454$

Number $3: 455^{-6}$ I I

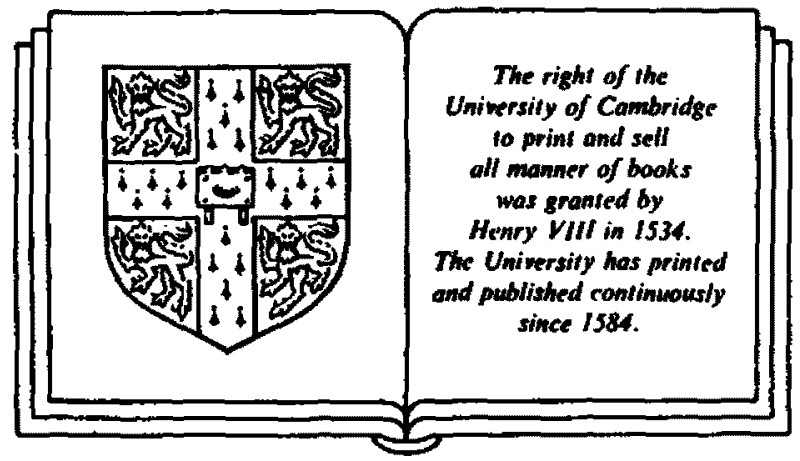

\section{Cambridge}

at the University Press

I 986 


\section{PUBLISHED BY}

THE PRESS SYNDICATE OF THE UNIVERSITY OF CAMBRIDGE The Pitt Building, Trumpington Street, Cambridge CB2 I RP 32 East 57th Street, New York, NY 10022 Io Stamford Road, Oakleigh, Melbourne 3 I66, Australia

(C) Cambridge University Press 1986 


\section{CONTENTS}

\section{VOLUME I 3}

Articles

Andrick, Gail Rex \& Tager-Flusberg, Helen. The acquisition of colour terms

Anselmi, Dina, Tomasello, Michael \& Acunzo, Mary. Young children's responses to neutral and specific contingent queries

Bennett-Kastor, Tina L. Cohesion and predication in child narrative

Brown, Barbara L. \& Leonard, LaURENCE B. Lexical influences on children's early positional patterns

Camarata, Stephen \& Leonard, Laurence B. Young children pronounce object words more accurately than action words

Carroll, John J. \& Gibson, Eleanor, J. Infant perception of gestural contrasts: prerequisites for the acquisition of a visually specified language

Chapman, Kathy L., Leonard, Laurence B. \& Mervis, Carolyn B. The effect of feedback on young children's inappropriate word usage

Demetras, M. J., Post, Kathryn Nolan \& Snow, Catherine E. Feedback to first language learners: the role of repetitions and clarification questions

Donahue, Mavis. Phonological constraints on the emergence of two-word utterances

Dromi, Esther \& Berman, Ruth A. Language-specific and languagegeneral in developing syntax

Foster, SUSAN H. Learning discourse topic management in the preschool years

Freeburg, Thomas J. \& Lippman, Marcia Z. Factors affecting discrimination of infant cries

Gandour, Jack, Petty, Soranee Holasuit, Dardarananda, Rochana, Dechongkit, Sumalee \& Mukngoen, Sunee. The acquisition of the voicing contrast in Thai: a study of voice onset time in word-initial stop consonants

Gathercole, Virginia C. The acquisition of the present perfect: explaining differences in the speech of Scottish and American children

GolinKoff, RoBERTA MichNick. 'I beg your pardon?': the preverbal negotiation of failed messages

Harris, Paul L., Morris, Jeremy E. \& Terwogt, Mark Meerum. The early acquisition of spatial adjectives: a cross-linguistic study 
Papers, notes and reviews should be sent to Dr A. Cruttenden, Department of General Linguistics, University of Manchester, Manchester, $\mathrm{M}_{13}{ }_{9} \mathrm{PL}$, England. They should normally be written in English. Major articles should not exceed twenty printed pages.

Three copies of the typescript should be submitted, and of any revisions or resubmissions. Contributions should be clearly typed with double spacing, on one side of the paper only, using a conventional size of paper, preferably $\mathrm{A}_{4}$ (or $2 \mathrm{r} \cdot 6$ by $28 \mathrm{~cm}$ ). Authors should hold one copy for correction of proofs. Footnotes should not be used unless absolutely necessary, and should be listed on a separate sheet (double-spaced) at the end of the article. Tables and figures should be drawn on separate pages at the end of the article. Each table/figure should have a title, and there should be an indication in the body of the text as to placement. Tables and figures should each be numbered independently of examples of utterances, etc. A separate title-page should include the title, author's name and affiliation, together with the address to which proofs are to be sent. Titles should be so worded that the first part may be used as a running headline (with a maximum length of 40 characters, including spaces). An abstract of the article (max. I 20 words) should be typed on a separate sheet.

Chronological age should be stated in years, months and (where needed) days as follows: $4 ; 5 \cdot 17$. Cited forms should be underlined to represent italicization in print. Translational 'meanings' should be placed within single quotation marks. Emphasis should be marked by the use of small capitals. Phonetic transcriptions should, wherever possible, employ the symbols and conventions of the IPA; they must never be used in footnotes, and should in no case be narrower than absolutely necessary for the purpose.

References are to be made in the text thus: (Neisser 1967: 222). If the author's name is part of the text, the following form should be used: 'Piaget (1967: 131) investigates.... When a work written by three or more authors is referred to, all names should be given in the first citation, with an ampersand linking the last two; e.g. (Fraser, Bellugi \& Brown $\mathrm{r}_{96} 6_{3}$ ): in subsequent citations the first name only should be given, with 'et al.' added. Multiple references should be date-ordered.

All works referred to should be listed at the end of the article, double-spaced and in alphabetical order. The titles of journals should as far as possible be abbreviated according to the conventions of the Linguistic Bibliography of the Permanent International Committee of Linguists (CIPL). Examples of references (note the use of punctuation marks) are:

Brown, R. (1973). A first language: the early stages. Cambridge, MA: Harvard University Press.

Crystal, D. (i 986). Prosodic development. In P. Fletcher \& M. Garman (eds), Language acquisition: studies in first language development (2nd ed.). Cambridge: CUP

Clark, R. (1974). Performing without competence. FChLang r. I-IO.

Ferguson, C. A. \& Slobin, D. I. (eds) (1973). Studies of child language development. New York: Holt, Rinehart \& Winston.

With the exception of the title-page, book reviews should be submitted in the same form as articles. (Three copies should be sent.) The title-page should be of the following form:

M. Bowerman, Early syntactic development : a cross-linguistic study with special reference to Finnish. Cambridge: CUP, 1973. Pp. xii +302 .

Reviewed by Patrick Griffiths, Department of Language, University of York. 


\section{Journal of Child Language}

Volume ${ }_{3} 3$ Number 3 October 1986

\section{Articles}

Golinkoff, Roberta Michnick. 'I beg your pardon?': the preverbal page negotiation of failed messages

Hoek, Dorothy, Ingram, David \& Gibson, Deborah. Some possible causes of children's early word overextensions

Tomasello, Michael \& Farrar, Michael Jeffrey. Object permanence and relational words: a lexical training study

Lucariello, Joan \& Nelson, Katherine. Context effects on lexical specificity in maternal and child discourse

Wanska, Susan, K. \& Bedrosian, Jan L. Topic and communicative intent in mother-child discourse

Gathercole, Virginia C. The acquisition of the present perfect: explaining differences in the speech of Scottish and American children

Gandour, Jack, Petty, Soranee Holasuit, Dardarananda, Rochana, Dechongkit, Sumalee \& Mukngoen, Sunee. The acquisition of the voicing contrast in Thai: a study of voice onset time in word-initial stop consonants

Waller, Glenn. The use of 'left' and 'right' in speech: the development of listener-specific skills

Peterson, Carole. Semantic and pragmatic uses of 'but'

\section{Notes and Discussion}

Pye, Clifton. One lexicon or two?: an alternative interpretation of early bilingual speech

Vihman, Marilyn May. More on language differentiation

\section{Reviews}

Locke, Jонn L.: Phonological acquisition and change (Pamela Grunwell)

Rice, M. L. \& Ke MPER, S.: Child language and cognition (Martyn D. Barrett)

Index of Books Received

Acknowledgement 